\title{
The Influence of Several Range Improvements on Estimated Carrying Capacity and Potential Beef Production
}

\author{
TONY SVEJCAR AND MARTIN VAVRA
}

\begin{abstract}
A simple calculation is proposed for estimating carrying capacity of range sites based on seasonal forage quality and standing crop. The model estimates animal unit days a pasture can support. Potential beef production of a particular site was estimated by multiplying animal unit days by average daily gain as indicated from forage quality. Improved and unimproved portions of 4 plant communities (grassland, mixed conifer, lodgepole pine, and moist meadow) were compared for carrying capacity and potential beef production. Improvement generally resulted in large increases in both carrying capacity and potential beef production; however, only in the case of the grassland did range improvement extend the period during which weight gains could be expected. Calculations indicate that energy generally became limiting before crude protein. Forage quality was insufficient to maintain weight gains of growing animals after mid-summer. Advantages and limitations of the calculations are discussed.
\end{abstract}

Livestock production from rangelands could be increased if management was more closely coupled to seasonal changes in forage quality (Vavra and Raleigh 1976). Extending the period during which adequate nutrients are available to livestock has been accomplished by using seeded pastures to complement native range (Currie 1969, Smoliak and Slen 1974), and by grazing diverse vegetation types during the periods they are most likely to provide adequate nutrition (Valentine 1967). How'ver, determining the optimum period of use for individual pastures may be difficult when many plant communities and/or range improvements are involved.

A model of seasonal carrying capacity and potential animal production on various sites would help a manager in formulating a livestock management plan. Carrying capacity models based on nutritional requirements have been used to evaluate wild life habitat (Wallmo et al. 1977, Mautz 1978, Hobbs et al. 1982). Hilken (1984) used a carrying capacity model to help evaluate competition between livestock and big game. The objective of the present study was to assess the impact of several range improvements on potential livestock carrying capacity and weight gain. We used a simple model, a data base consisting of seasonal curves of standing crop and forage quality of important forages species, and NRC (1970) nutritional requirements in our calculations.

\section{Materials and Methods}

\section{Study Sites}

The study sites, which represented 4 plant communities, were located in Grant County, Ore. Plant community types were: (1)

\footnotetext{
Authors are former research assistant and professor of range nut rition. respectively. Oregon State University, Eastern Oregon Agricultural Research Center, Union 97883 Svejcar is currently research agronomist, USDA-ARS, Southwestern Livestock and Forage Research Station, El Reno, Okla. 73036

The authors wish to thank an anonymous reviewer for comments which improved the manuscript.

This report is Oregon State Agr. Exp. Sta. Tech. Paper 7065. The research was funded jointly by the Fastern Oregon Agr. Res. Center, Oregon State University, and the USDA Forest Service. under Project 1701 of the Pacific Northwest Forest and Range Exp. Sta.

Manuscript accepted February I. 1985
}

moist meadow, (2) bunchgrass grassland on deep soil, gentle slopes, (3) lodgepole pine ( Pinus contorta Dougl.)-pinegrass (Calainagrustis rubescens Buckl.)-huckleberry (Vaccinium scoparium Leiberg), and (4) mixed conifer-pinegrass-ash soils (Hall 1973). A portion of each study site had been improved. The improvements were as follows: (1) the moist meadow had been seeded to intermediate wheatgrass (Agropyron intermedium (Host.) Beauv.), timothy (Phleum pratense L.) and smooth brome (Bromus inermis Leyss.) about 15 years prior to sampling; (2) the grassland had been seeded to intermediate wheatgrass and alfalfa (Medicago sativa L.) 3 years prior to sampling; (3) the lodgepole pine site had been thinned 14 years prior to sampling, but had not been seeded; and (4) the mixed conifer site had been commercially logged and seeded to timothy and orchardgrass (Dactylis glomerata L.) 2 years prior to our first sampling. Primary forage species on the unimproved portion of each plant community were: (1) the moist meadow was dominated by cinquefoil (Potentilla sp.) and wyethia (Wyethia amplexicaulis Nutt.); (2) the grassland was mostly bluebunch wheatgrass (Agropyron spicatum (Pursh.) Scribn \& Smith) and Idaho fescue (Festuca idahoensis Elmer), but Sandberg's bluegrass (Poa sandbergii Vasey) and junegrass (Koeleria cristata Pers.) were also present; (3) the lodgepole pine understory was principally pinegrass (also the case on the thinned site); and (4) the mixed conifer understory was dominated by pinegrass and snowberry (Symphoricarpus albus (L.) Blake). A more detailed description of study sites can be found in Svejcar and Vavra (1985).

\section{Data Base}

During the growing seasons of 1980 and 1981 we estimated standing crop and forage quality of primary forage species (those we thought would amount to at least $10 \%$ of the standing crop) on the improved and unimproved portions of each plant community. A double sampling technique (Pechanec and Pickford 1937) was used to determine standing crop. On each sampling date in all treatments sixty $0.25-\mathrm{m}^{2}$ plots were estimated and every fifth plot was clipped to ground level, oven dried for $72 \mathrm{~h}$ at $65^{\circ} \mathrm{C}$ and weighed. Sites were sampled monthly (the third week of each month) during the period they are generally grazed. Sampling periods were as follows for the study sites: grassland-April to July; mixed conifer and lodgepole pine-June to September; and moist meadow-July to September.

Forage quality samples for individual species were also collected on each of the sampling dates. The primary forage species were clipped to about $50 \%$ utilization, oven dried, and ground in a Wiley Mill to pass through a $2-\mathrm{mm}$ screen. Samples were analyzed for $\%$ crude protein (CP) using a macro-Kjeldahl technique (AOAC 1970) and in vitro dry matter digestibility (IVDMD) using a modified Tilley and Terry (1963) technique.

\section{Model Development}

We chose 300-kg growing heifers as the class of livestock upon which to base nutrient requirements and daily intake. Values for nutrient requirement and daily intake were obtained from NRC (1970) tables. The model used to calculate heifer unit days (HUD) 
Table 1. Peak forage standing crop for each study site during the two study years.

\begin{tabular}{lcc}
\hline & \multicolumn{2}{c}{ Peak Forage Standing Crop $(\mathrm{Kg} / \mathrm{Ha})^{\prime}$} \\
\cline { 2 - 3 } Study site & 1980 & 1981 \\
\hline $\begin{array}{l}\text { Grassland } \\
\text { Unimproved }\end{array}$ & $766 \pm 53$ & $541 \pm 41$ \\
$\quad$ Improved & $2773 \pm 187$ & $1675 \pm 85$ \\
$\begin{array}{c}\text { Moist Meadow } \\
\text { Unimproved }\end{array}$ & $314 \pm 31$ & $462 \pm 48$ \\
Improved & $1412 \pm 103$ & $1264 \pm 90$ \\
$\begin{array}{l}\text { Mixed Conifer } \\
\text { Unimproved }\end{array}$ & $408 \pm 29$ & $251 \pm 18$ \\
Improved & $2680 \pm 461$ & $1566 \pm 148$ \\
Lodgepole Pine & $116 \pm 12$ & $89 \pm 10$ \\
Unimproved & $170 \pm 14$ & $208 \pm 21$ \\
Improved & & \\
\hline
\end{tabular}

1 Values are mean \pm standard error.

of grazing available from a pasture was similar in form to that used by Hobbs (1982):

$$
\text { HUD }=\frac{\sum_{i=1}^{n}(\text { AFi } \times N C i)}{\text { DI } \times N R}
$$

where $\mathrm{n}=$ number of primary forage species, $\mathrm{AFi}=$ forage available from species $\mathrm{i}, \mathrm{NCi}=$ nut rient content of species $\mathrm{i}, \mathrm{Dl}=$ daily intake of a $300 \mathrm{~kg}$ growing heifer, and $\mathrm{NR}=$ nutrient requirement of a 300 $\mathrm{kg}$ growing heifer. We assumed $50 \%$ of the standing crop of primary forage species was available. Carrying capacity was calculated on the basis of both CP and metabolizable energy (ME). Conversion of IVDMD to ME was necessary because energy is expressed on an ME basis in NRC (1970) tables. We converted IVDMD to digestible energy (DE) with the formula of Rittenhouse et al. (1971): DE (Mcal $/ \mathrm{kg})=.038(\%$ IVDMD) + 0.18, and DE was converted to $\mathrm{ME}$ using the relationship provided by NRC (1970): $\mathrm{ME}(\mathrm{Mcal} / \mathrm{kg})=\mathrm{DE}(\mathrm{Mcal} / \mathrm{kg}) \times .82$. Calculations were made for improved and unimproved portions of all communities on all sampling dates. Thus, the model provided an estimate of HUD per hectare based on quantity and quality of available forage on a particular sampling date.

Potential beef production of a pasture was calculated by multiplying carrying capacity (HUD per hectare) and average daily gain (ADG). Values of ADG were also obtained from NRC (1970) tables for $300-\mathrm{kg}$ growing heifers. Average daily gain is dependent on nutrient levels in the forage. In many cases nutrients were below minimum requirements for weight gains; in such cases we calculated carrying capacity and noted that weight gains would not be expected.

\section{Results}

The range improvements increased forage standing crop on all communities during both years (Table 1). On the 2 nonforested sites (grassland and moist meadow), the seeding of introduced species increased standing crop about 3 -fold. On the mixed conifer site, thinning of the overstory and seeding introduced species increased standing crop over 6-fold, whereas thinning a one on the lodgepole pine site resu.ted in about a 1 -fold increase over the 2 -year period. The influence of the improvements on forage quality was less obvious. Adding a legume had the greatest impact, particularly in terms of CP (Table 2). The 2 improved forested sites tended to have lower CP levels than their unimproved counterparts. It should be noted that sampling dates were not constant across communities. This is one of the reasons for the high $\mathrm{CP}$ levels recorded for all species on the grassland site. In all cases forage quality was highest on the first sampling date, and lowest on the last sampling date. Seasonal curves of forage quality were consistent among years on each site (Svejcar and Vavra 1985).

On the grassland site ME became limiting before $\mathrm{CP}$ on both improved and unimproved sites in 1980 (Table 3). In 1981 this was also the case for the unimproved site, but on the improved site neither nutrient reached limiting levels during the sampling period. Carrying capacity and potential beef production were generally lower if calculated on an ME basis. The improved site had carrying capacities 2 to 4 times higher than the unimproved site. Nutrient deficiencies should limit weight gains on the unimproved site after May, whereas forage quality on the improved site should

Table 2. Relative contribution of individual species to peak forage standing crop on each study site, and range in \% crude protein (CP) and in vitro dry matter digestibility (IVDMD) for each species. Values are from two study years.

\begin{tabular}{|c|c|c|c|c|}
\hline & \multirow[b]{2}{*}{ Grassland } & \multirow{2}{*}{$\begin{array}{l}\% \text { Contribution To } \\
\text { Peak Standing Crop }\end{array}$} & \multicolumn{2}{|c|}{ Range of: } \\
\hline & & & $\mathrm{CP}$ & IVDMD \\
\hline Unimproved & $\begin{array}{l}\text { bluebunch wheatgrass } \\
\text { ldaho fescue } \\
\text { Sandberg's bluegrass } \\
\text { junegrass } \\
\text { intermediate wheatgrass } \\
\text { alfalfa }\end{array}$ & $\begin{array}{r}32 \\
43 \\
17 \\
8 \\
56 \\
44\end{array}$ & $\begin{array}{l}18.3-6.0 \\
19.8-4.5 \\
17.9-2.3 \\
20.5-3.9 \\
20.8-6.5 \\
35.7-15.8\end{array}$ & $\begin{array}{l}68.6-46.5 \\
69.1-43.7 \\
74.9-38.1 \\
73.4-38.9 \\
77.9-51.9 \\
77.1-64.0\end{array}$ \\
\hline Improved & Moist Meadow & & & \\
\hline \multirow[t]{2}{*}{ Improved } & $\begin{array}{l}\text { cinquefoil } \\
\text { wyethia } \\
\text { intermediate wheatgrass } \\
\text { timothy } \\
\text { smooth brome }\end{array}$ & $\begin{array}{l}71 \\
29 \\
21 \\
56 \\
23\end{array}$ & $\begin{array}{r}11.3-5.5 \\
11.1-6.0 \\
10.0-3.2 \\
8.7-2.3 \\
11.9-2.4\end{array}$ & $\begin{array}{l}66.7-54.4 \\
83.3-74.3 \\
74.6-48.9 \\
74.7-47.4 \\
76.3-50.5\end{array}$ \\
\hline & Mixed Conifer & & & \\
\hline Unimproved & $\begin{array}{l}\text { pinegrass } \\
\text { snowberry } \\
\text { timothy } \\
\text { orchardgrass }\end{array}$ & $\begin{array}{l}46 \\
54 \\
51 \\
49\end{array}$ & $\begin{array}{l}15.6-7.2 \\
16.5-6.5 \\
12.0-3.1 \\
13.9-4.9\end{array}$ & $\begin{array}{l}63.5-48.8 \\
65.3-54.7 \\
72.5-46.9 \\
72.0-49.2\end{array}$ \\
\hline Improved & Lodgepole Pine & & & \\
\hline $\begin{array}{l}\text { Unimproved } \\
\text { Improved }\end{array}$ & $\begin{array}{l}\text { pinegrass } \\
\text { pinegrass }\end{array}$ & $\begin{array}{l}100 \\
100\end{array}$ & $\begin{array}{l}18.3-7.2 \\
15.3-4.9\end{array}$ & $\begin{array}{l}66.2-49.7 \\
63.9-46.6\end{array}$ \\
\hline
\end{tabular}


Table 3. Estimated heifer unit days (HUD) and beef production (Kg BEEF) per hectare for $300 \mathrm{~kg}$ heifers on improved and unimproved grassland sites. Values were calculated on the basis of metabolizable energy (ME) or crude protein (CP) available in forage on the given dates. ${ }^{1}$

\begin{tabular}{|c|c|c|c|c|c|c|c|c|}
\hline \multirow[t]{3}{*}{ Date } & \multicolumn{4}{|c|}{1980} & \multicolumn{4}{|c|}{1981} \\
\hline & \multicolumn{2}{|c|}{ ME (Mcal/kg) } & \multicolumn{2}{|c|}{$\mathrm{CP}(\%)$} & \multicolumn{2}{|c|}{ ME (Mcal/kg) } & \multicolumn{2}{|c|}{$\mathrm{CP}(\%)$} \\
\hline & HUD & $\mathrm{Kg} \mathrm{BEEF}$ & HUD & $\mathrm{Kg}$ BEEF & HUD & $\mathrm{Kg} \mathrm{BEEF}$ & HUD & Kg Beef \\
\hline \multicolumn{9}{|l|}{ April } \\
\hline Unimproved & 7 & 5 & 12 & 9 & 7 & 5 & 10 & 8 \\
\hline Improved & 19 & 14 & 34 & 26 & 10 & 7 & 22 & 16 \\
\hline \multicolumn{9}{|l|}{ May } \\
\hline Unimproved & 35 & 17 & 35 & 18 & 14 & 11 & 16 & 12 \\
\hline Improved & 143 & 108 & 229 & 172 & 34 & 26 & 53 & 40 \\
\hline \multicolumn{9}{|l|}{ June } \\
\hline Unimproved & 81 & No Gain & 63 & 16 & 59 & No Gain & 33 & 17 \\
\hline Improved & 165 & 124 & 232 & 174 & 105 & 79 & 164 & 123 \\
\hline \multicolumn{9}{|l|}{ July } \\
\hline Unimproved & 63 & No Gain & 60 & No Gain & 46 & No Gain & 59 & No Gain \\
\hline Improved & 288 & No Gain & 179 & 90 & 105 & 53 & 120 & 90 \\
\hline
\end{tabular}

'An explanation of calculations appears in the methods section. Calculations of potential carrying capacity and beef production assume a pasture is grazed only during a given month, thus months cannot be added to estimate total seasonal potential.

Allow weight gains for 1 to 2 months longer.

In the mixed conifer community $\mathrm{ME}$ became limiting before $\mathrm{CP}$, the exception was the improved site in 1980 when both nutrients became limiting s.multaneously (Tabli 4 ). The unimproved site maintained $C P$ levels adequate for weight gains for 1 additional month relative to the improved site during both years; however, energy was limiting after June on both sites. The carrying capacity of the improved site was 2 to 10 times greater than that of the unimproved site. On the lodgepole pine site ME became limiting before CP (Table 5). On the basis of ME, yearling heifers would be expected to gain weight during June of both years on the unimproved site. No weight gains were expected after June on either site. However, on the basis of $\mathrm{CP}$, weight gains could be expected for about 2 months longer. The improved lodgepole pine site could potentially support more animals than the unimproved site on all sampling dates. The treatment differences in carrying capacity were more evident during 1981 than 1980.

Growing heifers would be expected to gain weight only during the first grazing period (July) on either of the moist meadow treatments (Table 6). Carrying capacity of the improved site was 2 to 5 times higher during the period forage was available. The forbs on the unimproved site senesced durin mid to late summer of both years and after senescence provided essentially no forage. Therefore, the improved site could carry animals longer than the unimproved site, but late summer weight gains would not be expected.

\section{Discussion}

\section{Some Uses and Limitations of the Model}

Calculation of range carrying capacity has generally been based on the animal unit month (AUM) concept. The official definition of an AUM is the amount of forage a 453-kg (1,000 lb) cow consumes in a month based on a daily consumption rate of $11.8 \mathrm{~kg}$ (26 lb) (Range Term Glossary Committee 1974). This value is independent of forage quantity and does not account for the effects of forage quality on intake. The proposed model, which takes into account both quantity and quality of forage, should more accurately predict carrying capacity than AUM estimates based solely on standing crop.

The NRC tables are useful in determining if a site is potentially deficient in a given nutrient. The combination of carrying capacity and ADG per animal provides an estimate of site beef production potential. The model could easily be expanded to include several classes of livestock and thus indicate which sites are most apt to meet the requirements of a particular class.

Table 4. Estimated heifer unit days (HUD) and beef production (Kg BEEF) per hectare for $300 \mathrm{~kg}$ heifers on improved and unimproved mixed conifer sites. Values were calculated on the basis of metabolizable energy (ME) or crude protein (CP) available in forage on the given dates.'

\begin{tabular}{|c|c|c|c|c|c|c|c|c|}
\hline \multirow[t]{3}{*}{ Date } & \multicolumn{4}{|c|}{1980} & \multicolumn{4}{|c|}{1981} \\
\hline & \multicolumn{2}{|c|}{$\mathrm{ME}(\mathrm{Mcal} / \mathrm{kg})$} & \multicolumn{2}{|c|}{$C P(\%)$} & \multicolumn{2}{|c|}{$\mathrm{ME}(\mathrm{Mcal} / \mathrm{kg})$} & \multicolumn{2}{|c|}{ CP $(\%)$} \\
\hline & HUD & $\mathrm{Kg}$ BEEF & HUD & $\mathrm{Kg}$ BEEF & HUD & $\mathrm{Kg} \mathrm{BEEF}$ & HUD & $\mathrm{Kg}$ Beef \\
\hline $\begin{array}{l}\text { June } \\
\text { Unimproved } \\
\text { Improved }\end{array}$ & $\begin{array}{r}8 \\
41\end{array}$ & $\begin{array}{c}4 \\
31\end{array}$ & $\begin{array}{c}8 \\
44\end{array}$ & $\begin{array}{r}6 \\
22\end{array}$ & $\begin{array}{l}17 \\
30\end{array}$ & $\begin{array}{r}9 \\
23\end{array}$ & $\begin{array}{l}13 \\
34\end{array}$ & $\begin{array}{r}9 \\
26\end{array}$ \\
\hline $\begin{array}{l}\text { July } \\
\text { Unimproved } \\
\text { Improved }\end{array}$ & $\begin{array}{r}21 \\
220\end{array}$ & $\begin{array}{l}\text { No Gain } \\
\text { No Gain }\end{array}$ & $\begin{array}{r}12 \\
232\end{array}$ & $\stackrel{9}{\text { No Gain }}$ & $\begin{array}{r}21 \\
103\end{array}$ & $\begin{array}{l}\text { No Gain } \\
\text { No Gain }\end{array}$ & $\begin{array}{l}13 \\
84\end{array}$ & $\begin{array}{l}10 \\
21\end{array}$ \\
\hline $\begin{array}{l}\text { August } \\
\text { Unimproved } \\
\text { Improved }\end{array}$ & $\begin{array}{r}41 \\
261\end{array}$ & $\begin{array}{l}\text { No Gain } \\
\text { No Gain }\end{array}$ & $\begin{array}{r}25 \\
231\end{array}$ & $\begin{array}{l}13 \\
58\end{array}$ & $\begin{array}{r}26 \\
144\end{array}$ & $\begin{array}{l}\text { No Gain } \\
\text { No Gain }\end{array}$ & $\begin{array}{r}17 \\
144\end{array}$ & No $\stackrel{8}{\text { Gain }}$ \\
\hline $\begin{array}{l}\text { September } \\
\text { Unimproved } \\
\text { Improved }\end{array}$ & $\begin{array}{r}38 \\
241\end{array}$ & $\begin{array}{l}\text { No Gain } \\
\text { No Gain }\end{array}$ & $\begin{array}{r}43 \\
153\end{array}$ & $\begin{array}{l}\text { No Gain } \\
\text { No Gain }\end{array}$ & $\begin{array}{r}26 \\
142\end{array}$ & $\begin{array}{l}\text { No Gain } \\
\text { No Gain }\end{array}$ & $\begin{array}{r}27 \\
101\end{array}$ & $\begin{array}{l}\text { No Gain } \\
\text { No Gain }\end{array}$ \\
\hline
\end{tabular}

'An explanation of calculations appears in the methods section. Calculations of potential carrying capacity and becf production assume a pasture is grazed only during a given tuonth, thus months cannot be added to estimate total seasonal potential. 
Table 5. Estimated heifer unit days (HUD) and beef production (Kg BEEF) per hectare for $300 \mathrm{~kg}$ heifers on improved and unimproved lodgepole pine sites. Values were calculated on the basis of metabolizable energy (ME) or crude protein (CP) available in forage on the given dates. ${ }^{1}$

\begin{tabular}{|c|c|c|c|c|c|c|c|c|}
\hline \multirow[t]{3}{*}{ Date } & \multicolumn{4}{|c|}{1980} & \multicolumn{4}{|c|}{1981} \\
\hline & \multicolumn{2}{|c|}{ ME (Mcal/kg) } & \multicolumn{2}{|c|}{ CP $(\%)$} & \multicolumn{2}{|c|}{ ME (Mcal/kg) } & \multicolumn{2}{|c|}{ CP $(\%)$} \\
\hline & HUD & $\mathrm{Kg}$ BEEF & HUD & $\mathrm{Kg}$ BEEF & HUD & $\mathrm{Kg}$ BEEF & HUD & $\mathrm{Kg}$ Beef \\
\hline \multicolumn{9}{|l|}{ June } \\
\hline Unimproved & 3 & 1 & 3 & 3 & 3 & 1 & 4 & 3 \\
\hline Improved & 6 & 3 & 8 & 6 & 17 & No Gain & 13 & 10 \\
\hline \multicolumn{9}{|l|}{ July } \\
\hline Unimproved & 5 & No Gain & 6 & 4 & 8 & No Gain & 5 & 4 \\
\hline Improved & 8 & No Gain & 9 & 7 & 20 & No Gain & 13 & 10 \\
\hline \multicolumn{9}{|l|}{ August } \\
\hline Unimproved & 10 & No Gain & 8 & 4 & 9 & No Gain & 6 & 3 \\
\hline Improved & 16 & No Gain & 14 & 4 & 19 & No Gain & 25 & No Gain \\
\hline \multicolumn{9}{|l|}{ September. } \\
\hline Unimproved & 11 & No Gain & 12 & No Gain & 8 & No Gain & 11 & No Gain \\
\hline Improved & 15 & No Gain & 12 & No Gain & 18 & No Gain & 16 & No Gain \\
\hline
\end{tabular}

Table 6. Estimated heifer unit days (HUD) and beef production (Kg BEEF) per hectare for $300 \mathrm{~kg}$ heifers on improved and unimproved moist meadows sites. Values were calculated on the basis of metabolizable energy (ME) or crude protein (CP) available in forage on the given dates. ${ }^{1}$

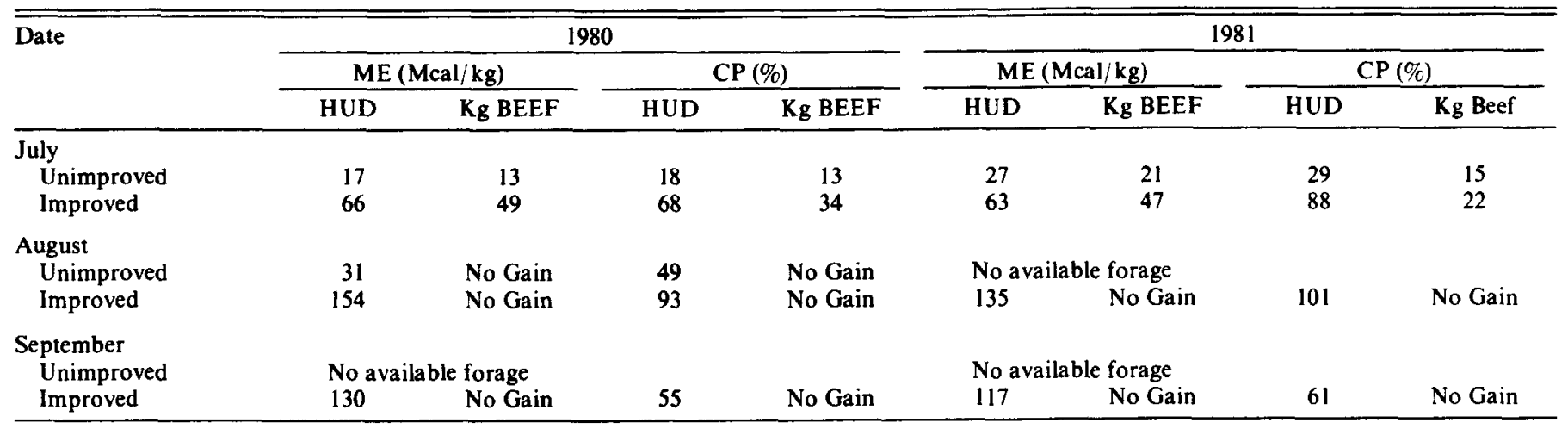

An explanation of calculations appears in the methods section. Calculations of potential carrying capacity and beef production assume a pasture is grazed only during a given month, thus months cannot be added to estimate total seasonal potential.

The model can be applied to range improvements by allowing an estimate of the proper mix of improved and unimproved range in a particular grazing scheme. Improved pastures are often used during specific periods, which led Evans (1982) to suggest that "as the area of improved pasture is increased stocking rates need to be increased to fully utilize them, which puts greater grazing pressure on the unimproved pasture at other times".

The data base we used for estimating carrying capacity and potential beef production contained several potential inadequacics. Measurements of seasonal trend in forage quantity and quality were made only on major forage species; however, in diverse communities there may be periods when minor species make important contributions to diet quality (Holechek et al. 1982, a,b). We also assumed uniform $50 \%$ utilization of the major forage species. Certainly grazing pattern and diet selection are seldom uniform and can be influenced by such factors as species associations, grazing system, topography, climate, etc. Animal diets tend to be higher in nutrients than the range as a whole (Arnold 1981). These factors suggest our calculations are conservative and actual weight gains might occur during periods they were not predicted.

Animal requirements printed in NRC tables are geared toward confinement fed rather than free-ranging animals. There have been many technical problems in obtaining accurate intake values for grazing animals (Cordova et al. 1978). At present NRC tables represent the most complete set of animal requirement values available and should suffice for calculating relative differences between range sites and/or improvement practices. Holechek et al. (1981) reported that the relationship between actual amount of nutrients consumed and NRC requirements reflected levels of ADG measured on free-ranging yearling heifers.

\section{Estimated Carrying Capacity and Beef Production}

Range improvements can be used to increase carrying capacity and / or fill critical gaps in forage supply. Often one of the major problems encountered in improving pasture systems is the seasonal nature of forage production (Reid and Jung 1982). As Evans (1982) has indicated, improved pastures will be most useful when they can alleviate nuritional stress during periods critical to animal production. Our calculations show that ringe improvement increased carrying capacity on all sampling dates in all 4 plant communities. However, calculation of potential weight gain of yearling heifers suggests only in the case of the improved grassland was there a consistent increase in the period during which heifers would be expected to gain weight (Tables 3-6). 
The nature of the range improvement and the species involved can influence the relationship between seasonal forage production and forage quality. Alfalfa was responsible for extending the nutritionally adequate period on the improved grassland (Svejcar and Vavra 1985). White and Wight (1981) also found that dryland alfalfa maintained relatively high digestibility late in the growing season. On forested sites it has been well documented that overstory removal can increase production of forage (Young 1965, McConnell and Smith 1970, Dodd et al. 1972. Stuth and Winward 1976). However, thinning did not extend the period during which we calculated weight gains. In fact, during 1 of the 2 study years, thinning reduced pinegrass forage quality on the lodgepole pine site (Svejcar and Vavra 1985). Thinning increases light levels and temperature in the understory, which may accelerate phenology of some species. Snow was present about 2 weeks longer on the unthinned relative to the thinned lodgepole pine site. On the mixed conifer site there were species differences to consider as well. McLean and Clark (1980) suggest that orchardgrass and timothy develop and mature faster than pinegrass.

Late summer nutritional deficiencies in pastures are common in regions where summer drought is a normal part of the climatic region. In a review of animal production from Mediterranean-type pastures, Allden (1982) stated that livestock gain weight during spring and lose weight during summer regardless of stocking rate or pasture type. Areas with a Mediterranean climate tend to be hotter and have a longer period of summer drought than the Pacific Northwest, but some of the pasture problems are similar. A comparison among the communities we sampled indicates the importance of meadows for filling the late summer gap in nutritionally adequate forage. On the forb-dominated unimproved meadow, forage senesced and became unavailable soon after midsummer. It should be noted that the meadow was not in good range condition (Hall 1973). The improved meadow site was capable of carrying livestock after mid-summer, but calculations indicate weight gains would not be expected. Extending the period during which meadows are nutritionally adequate would help considerably in complcting the summer forage cycle in this region. In general, research aimed at filling the late summer gap in forage quality is warranted.

\section{Literature Cited}

Allden, W.G. 1982. Problems of animal production from Mediterrantan pastures, p. 45-65. In: J.B. Hacker (ed), Nutritional limits to animal production from pastures. Commonwealth Agr. Buraux. Slough. UK.

AOAC. 1970. Official methods of analysis (11th Edition). Ass. Official Anal. Chem. U.S. U.S. Government Printing Office, Washington D.C.

Arnold, G.W. 1981. Grazing behaviour, p. 79-104. In: F.H.W. Morley (ed), World animal science, grazing animals. Elsevier Scientific Publ. Co.. New York

Cordova, F.J., Joe D. Wallace, and R.E. Pieper. 1978. Forage intake by grazing livestock: A Review. J. Range Manage. 31:430-438.

Currie, P.O. 1969. Use seeded ranges in your management. J. Range Manage. 22:432-434

Dodd, C.J.H., A. McLean, and V.C. Brink. 1972. Grazing values as related to trec-crown covers. Can. J. For. Res. 2:185-189.

Evans, T.R. 1982. Overcoming nutritional limitations through pasture management, p. 343-361. In: J.B. Hacker (ed). Nutritional limits to animal production from pastures. Commonwealth $A$ gr. Bureaux, Slough UK.
Hall, F.C. 1973. Plant communities of the Blue Mountains in eastern Oregon and southeastern Washington. USDA Forest Service Agr. Handbk No. 553.

Hilken, T.O. 1984. Food habits and dict quality of deer and cattle and herbage production of a sagebrush-grassland range. M.S. Thesis. Oregon State Univ., Corvallis.

Hobbs, N.T., D.L. Baker, J.E. Ellis, D.M. Swift and R.A. Green. 1982. Energy and nit rogen-based estimates of elk winter-range carrying capacity. J. Wildl. Manage. 46:12-21.

Holechek, J.L., M. Vavra, and J. Skovlin. 1981. Diet quality and performance of cattle on forest and grassland range. J. Anim. Sci. 53:291-298.

Holechek, J.L., M. Vavra, J. Skovlin, and W.C. Krueger. 1982a. Cattle diets in the Blue Mountains of Oregon, I. Grasslands. J. Range Manage. 35:109-112.

Holechek, J.L., M. Vavra, J. Skovlin, and W.C. Krueger. 1982b. Cattle diets in the Blue Mountains of Oregon. Il. Forests. J. Range Manage. 35:239-242.

Mautz, W.W. 1978. Nutrition and carrying capacity, p. 321-348. In: J.L. Schmidt and D.L. Gilbert (eds), Big game of North America: ecology and management. Stackpole, Harrisburg, $P a$.

McConnell, B.R., and J.G. Smith. 1970. Response of understory vegetation to ponderosa pine thinning in eastern Washington. J. Range Manage. 23:209-212.

McLean, A., and M.B. Clark. 1980. Grass, trees, and cattle on clearcutlogged areas. J. Range Manage. 33:213-217.

NRC. 1970. Nutrient requirements of beef cattle. Printing and Publishing Office, Nat. Acad Sci., Washington D.C.

Pechanec, J.F., and G.D. Pickford. 1937. A weight estimate method for determination of range or pasture production. J. Amer. Soc. Agron. 29:894-904.

Range Term Glossary Committee. 1974. A glossary of terms used in range management. Soc. for Range Manage, Denver, Colo.

Keid, K.L., and G.A. Jung. 1982. Problems of animal production from temperate pastures, p. 21-43. In: J.B. Hacker (ed). Nutritional limits to animal production from pastures. Commonwealth Agr. Bureaux. Slough. UK.

Rittenhouse, L.R., C.L. Streeter, and D.C. Clanton. 1971. Estimating digestible energy from digestible dry and organic matter in diets of grazing cattle. J. Range Manage. 24:73-75.

Smoliak, S., and S.B. Slen. 1974. Beef production on native range, crested wheatgrass and Russian wildrye pastures. J. Range Manage. 27:433-436.

Stuth, J.W., and A.J. Winward. 1976. Logging impacts on bitterbrush in the lodgepole pine-pumice region of cent ral Oregon. J. Range Manage. 29:453-456.

Svejcar, T., and M. Vavra. 1985. Seasonal forage quality and production on four native and improved plant communities in eastern Oregon. Oregon State University Agr. Exp. Station Tech. Bull. No. 149.

Tilley, J.M., and R.A. Terry. 1963. A two-stage technique for the in vitro digestion of forage crops. J. Brit. Grassl. Soc. 18:104-111.

Valentine, K.A. 1967. Seasonal suitability, a grazing system for ranges of diverse vegetation types and condition classes. J. Range Manage. 20:395-397

Vavra, M., and R.J. Raleigh. 1976. Coordinating beef cattle management with the range forage resource. J. Range Manage. 29:449-452.

Wallmo, O.C., L.H. Carpenter, W.L. Regelin, R.B. Gill, and D.L. Baker. 1977. Evaluation of deer habitat on a nutritional basis. J. Range Manage. 30: 122-127.

White, L.M., and J.R. Wight. 1981. Scasonal dry matter yicld and digestibility of seven grass species, alfalfa, and cicer milkvetch in eastern Montana. Agron. 1. 73:457-462.

Young, J.A. 1965. Forage production and utilization in a mixed conifer forest in the Wallowa Mountain Foothills. Ph. D. Thesis. Oregon State Univ.. Corvallis. 